\title{
Efek Waktu Paparan Genistein terhadap Pembentukan Jantung Embrio Zebrafish
}

\section{The Effect of Genistein Exposure Time of Zebrafish Cardiac Formation}

\author{
Devi Anggraeni $P^{1}$, Habiba Aurora ${ }^{2}$, Diana Lyrawati ${ }^{3}$ \\ ${ }^{1}$ Program Studi Pendidikan Dokter Fakultas Kedokteran Universitas Brawijaya Malang \\ ${ }^{2}$ Laboratorium Ilmu Faal Fakultas Kedokteran Universitas Brawijaya Malang \\ ${ }^{3}$ Laboratorium Farmasi Klinis Fakultas Kedokteran Universitas Brawijaya Malang
}

\begin{abstract}
ABSTRAK
Genistein merupakan fitoestrogen yang telah banyak diteliti manfaatnya terhadap kesehatan. Efek samping penggunaan genistein belum banyak dipelajari. Pada masa awal perkembangan paparan genistein dalam dosis tinggi dapat menyebabkan gangguan pertumbuhan dan meningkatkan angka kematian. Penelitian ini bertujuan membuktikan pengaruh perbedaan waktu paparan genistein terhadap perkembangan jantung zebrafish, melalui pengamatan pada frekuensi denyut jantung dan ketebalan pericardium dari embrio zebrafish. Embrio zebrafish dipapar dengan genistein 10 $\mu \mathrm{M}$ sejak 2, 24, dan $48 \mathrm{hpf}$ (hours post fertilization). Pengamatan dilakukan pada $72 \mathrm{hpf}$ pada mikroskop dengan perbesaran obyektif 40x, pengukuran ketebalan pericardium dilakukan menggunakan mikrometer pada bagian lateral embrio. Hasil penelitian ini menunjukkan bahwa paparan genistein pada awal tahap perkembangan zebrafish menyebabkan penurunan frekuensi denyut jantung dan edema perikardium. Efek tersebut akan berkurang dengan penundaan awal pemberian paparan genistein.
\end{abstract}

Kata Kunci: Denyut jantung, edema perikardium, genistein, zebrafish

\begin{abstract}
Genistein is a phytoestrogen that have been studied for their health benefits. The side effect of genisteinis not completely known. High dose of genistein exposure on the developmental stage could disturb fetal growth and increase mortality rate. The aim of this study is to demonstrate the effect of different exposure times of genistein on zebrafish cardiac formation, by observing the heart rate and the thickness of embryo's pericardium. Zebrafish embryos were exposed to $10 \mu \mathrm{M}$ genistein from 2, 24, and 48 hours post fertilization (hpf). The embryos were observed at 72 hpf using microscope with 40x objective lense, pericardium thickness were measured by micrometer on the lateral side of the embryos. The results of this study show that genistein exposure on early stage of zebrafish development could decrease the heart rate and cause pericardial oedema. These effect is decrease by delaying the genistein exposure.
\end{abstract}

Keywords: Heart rate, percardial oedema, genistein, zebrafish

Jurnal Kedokteran Brawijaya, Vol. 28, No. 1, Februari 2014; Korespondensi: Habiba Aurora. Laboratorium Ilmu Faal Fakultas Kedokteran Universitas Brawijaya Malang, Jl. Veteran Malang Tel. (0341) 567192 Email: habiba_aurora@yahoo.com 


\section{PENDAHULUAN}

Endocrine-disrupting chemichals(EDCs) merupakan bahan kimia dari luar tubuh yang berpotensi memodulasi atau mengganggu sintesis, sekresi, transport, ikatan, aksi, atau eliminasi hormon endokrin di dalam tubuh. Salah satu contoh EDCs alami adalah fitoestrogen (1). Genistein merupakan golongan fitoestrogen yang banyak terkandung pada kedelai (2). Efek fitoestrogen bersifat organ specific, pada organ tertentu menghambat pertumbuhan tumor, sedangkan pada organ yang lain tidak berefek bahkan meningkatkan tumorigenitas. Pengaruh yang ditimbulkan oleh fitoestrogen sangat bergantung pada waktu paparan dan lama pemberian (3). Genistein dapat mempengaruhi berbagai jalur kimia dan memiliki mekanisme kerja yang kompleks pada sel hidup. Salah satu target biokimia genistein pada sel adalah reseptor estrogen. Hal ini dikarenakan kemiripan struktur kimia genistein dengan estrogen (4).

Embrio zebrafish banyak digunakan sebagai model penelitian toksisitas bahan kimia, karena embriogenesis yang cepat dan memiliki larva yang transparan (5). Jantung pada zebrafish merupakan organ yang pertama kali terbentuk dan memiliki kemiripan dengan embriogenesis jantung pada manusia. Perbandingan spesifik perkembangan jantung 24 jam setelah fertilisasi pada zebrafish sebanding dengan usia 3 minggu intrauterin pada manusia (6).

Telah banyak penelitian membuktikan kegunaan genistein dalam menurunkan risiko penyakit kardiovaskular (7). Disisi lain penelitian Kim et al menunjukkan bahwa paparan genistein pada embrio zebrafish menyebabkan efek negatif berupa penurunan denyut jantung (8). Oleh karena itu, diperlukan penelitian lebih lanjut untuk membuktikan pengaruh perbedaan waktu paparan genistein pada embrio terhadap frekuensi denyut jantung zebrafish.

\section{METODE}

\section{Pemeliharaan Ikan}

Pemeliharaan zebrafish dewasa dilakukan dalam akuarium berisi $60 \mathrm{~L}$ air. Suhu air dijaga pada suhu $25-30^{\circ} \mathrm{C}$. Pengaturan cahaya dengan periode terang selama 14 jam dimulai dari pukul 8.00 pagi dan 10 jam periode gelap. Pemberian makanan dengan tetramin diberikan dua kali dalam sehari (9).

\section{Pengambilan Telur}

Pengambilan telur dilakukan dengan meletakkan keranjang berjala pada akuarium zebrafish dewasa setelah pemberian makan terakhir, dan diambil 15-25 menit setelah periode terang dimulai. Telur yang diperoleh dicuci dengan medium embrio untuk dibersihkan dari debris (9).

\section{KulturEmbrio}

Telur yang terfertilisasi diletakkan pada piring kultur 6 sumur (30 embrio/8 $\mathrm{mL}$ embrio medium/sumur), dan diinkubasi pada suhu $28 \pm 0,5^{\circ} \mathrm{C}$. Embrio medium diganti satu kali setiap hari sesuai paparan yang diberikan. Pemaparan dibagi menjadi empat kelompok, yaitu kontrol (DMSO 0,05\%), paparan genistein $10 \mu \mathrm{M}$ sejak 2, 24, dan 48 hpf (10).

\section{Pengamatan}

Pengamatan dilakukan pada 72 hpf menggunakan mikroskop Leica dengan perbesaran obyektif 40x. Ketebalan perikardium diukur menggunakan mikrometer, dengan memposisikan bagian lateral embrio pada gelas objek, dan pengukuran dilakukan pada sisi lateral (11). Frekuensi denyut jantung dihitung selama 15 detik pada 10 embrio dari tiap kelompok, diulang tiga kali (12).

\section{Analisis Data}

Analisis statistik dalam penelitian ini menggunakan oneway analysis of varian (ANOVA) dilanjutkan dengan uji post hoc Tukey HSD dengan software SPSS 16. Nilai perbedaan dianggap bermakna jika $\mathrm{p}<0,05$.

\section{HASIL}

Pada penelitian ini embrio zebrafish dibedakan pada waktu awal pemaparan dengan genistein $10 \mu \mathrm{M}$ untuk mengamati pengaruhnya terhadap pembentukan jantung, melalui penghitungan frekuensi denyut jantung dan pengukuran ketebalan pericardium. Pada $72 \mathrm{hpf}$ dilakukan pengamatan terhadap embrio. Embrio yang dipapar genistein sejak 2 hpf menunjukkan hambatan pertumbuhan dibanding kelompok kontrol (Gambar 1). Terlihat defek morfologi berupa pembesaran perikardium, pembesaran yolk sac, tulang belakang tidak terbentuk sempurna, dan tidak ada embrio yang menetas.

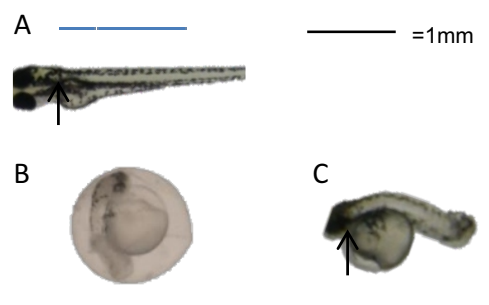

Gambar 1. Embrio zebrafish pada $72 \mathrm{hpf}$

Keterangan: (A) Embrio yang tidak dipapar genistein, (B) Embrio yang dipapar genistein sejak $2 \mathrm{hpf}$, (C) Embrio yang dipapar genistein sejak $2 \mathrm{hpf}$ dan dikeluarkan dari cangkang secara manual, menunjukkan adanya defek morfologis. Tanda panah menunjukkan gambaran perikardium.

Pada penghitungan frekuensi denyut jantung didapatkan adanya penurunan denyut jantung secara signifikan $(p<0,05)$ pada semua kelompok perlakuan yang dipapar genistein $10 \mu \mathrm{M}$ dibanding kelompok kontrol (Tabel 1). Penurunan denyut jantung paling besar terjadi pada kelompok yang dipapar genistein $10 \mu \mathrm{M}$ sejak $2 \mathrm{hpf}$ (79,1\%).

Tabel 1. Rata-rata jumlah frekuensi denyut jantung embrio zebrafish (denyut/menit)

\begin{tabular}{lccc}
\hline Kelompok & $\begin{array}{c}\text { Rata-rata jumlah } \\
\text { frekuensi denyut } \\
\text { jantung }\end{array}$ & $\begin{array}{c}\text { Standar } \\
\text { deviasi } \\
\text { (denyut/menit) }\end{array}$ & P (ANOVA) \\
\hline $\begin{array}{l}\text { Kontrol } \\
\text { Genistein 10 }\end{array}$ & $\begin{array}{l}\text { 130,40 } \\
\text { a }\end{array}$ & 6,43 & \\
$\mu$ M sejak 2 & $27,25^{\mathrm{b}}$ & 7,66 & 0,000 \\
hpf & & & \\
$\begin{array}{l}\text { Genistein 10 } \\
\mu M \text { sejak 24 }\end{array}$ & $42,53^{\mathrm{b}}$ & 13.10 & \\
hpf & & & \\
$\begin{array}{l}\text { Genistein 10 } \\
\mu M \text { sejak 48 }\end{array}$ & $72,13^{\mathrm{c}}$ & 7,43 & \\
hpf & & & \\
\hline
\end{tabular}

Keterangan: notasi $(a, b, c)$ yang berbeda menunjukkan perbedaan yang signifikan $(p<0,05)$ setelah uji Tukey 
Hasil pengukuran ketebalan perikardium menunjukkan terdapat peningkatan ketebalan perikardium pada semua kelompok yang dipapar genistein $10 \mu \mathrm{M}$ secara signifikan $(p<0,05)$ dibanding kelompok kontrol (Tabel 2). Peningkatan terbesar pada kelompok yang dipapar genistein $10 \mu \mathrm{M}$ pada $2 \mathrm{hpf}(79,67 \%)$. Peningkatan tersebut tidak berbeda secara signifikan $(p>0,05)$ dibanding kelompok yang dipapar genistein $10 \mu \mathrm{M}$ pada 24 maupun $48 \mathrm{hpf}$.

Tabel 2. Rata-rata hasil pengukuran ketebalan perikardium embrio zebrafish $(\mu \mathrm{m})$

\begin{tabular}{lccc}
\hline Kelompok & $\begin{array}{c}\text { Rata-rata hasil } \\
\text { pengukuran } \\
\text { ketebalan } \\
\text { perikardium }(\mu \mathrm{m})\end{array}$ & $\begin{array}{c}\text { Standar } \\
\text { deviasi }\end{array}$ & p(ANOVA) \\
\hline Kontrol & $98,33^{\mathrm{a}}$ & 3,82 & \\
Genistein 10 & $176,67^{\mathrm{b}}$ & 14,43 & 0,000 \\
$\mu \mathrm{M}$ sejak 2 & & & \\
$\mathrm{hpf}$ & $160^{\mathrm{b}}$ & 13,22 & \\
$\begin{array}{l}\text { Genistein 10 } \\
\mu \mathrm{M} \text { sejak 24 }\end{array}$ & & & \\
$\mathrm{hpf}$ & & & \\
Genistein 10 & $146,67^{\mathrm{b}}$ & 11,55 & \\
$\mu \mathrm{M}$ sejak 48 & & \\
$\mathrm{hpf}$ & & \\
\hline
\end{tabular}

Keterangan: notasi $(a, b)$ yang berbeda menunjukkan perbedaan yang signifikan $(p<0,05)$ setelah uji Tukey

\section{DISKUSI}

Dari hasil pengamatan didapatkan hambatan pertumbuhan pada kelompok embrio yang dipapar genistein sejak $2 \mathrm{hpf}$ dibanding kelompok kontrol menurut staging tahapan perkembangan zebrafish (13). Hasil tersebut memperkuat dugaan tentang beberapa mekanisme genistein dalam menghambat pertumbuhan, antara lain dengan mengganggu regulasi siklus sel, memodulasi transformasi growth factor beta-1 signaling pathway, sebagai antiangiogenesis, dan antioksidan (8).

Pemberian paparan genistein pada embrio zebrafish menyebabkan penurunan frekuensi denyut jantung dan terjadinya edema pericardium, yang diamati melalui pengukuran ketebalan pericardium. Penurunan frekuensi denyut jantung disertai edema perikardium pada embrio zebrafish juga didapatkan pada pemaparan 2,3,7,8Tetrachlorodibenzo-p-dioxin (TCDD) yang merupakan EDCs sintetis (11).

Genistein mempengaruhi embriogenesis zebrafish melalui kemampuannya meregulasi gen spesifik bergantung pada reseptor estrogen dan merangsang terjadinya apoptosis tanpa melalui reseptor estrogen (1). Pada jantung, estrogen melalui ikatannya dengan reseptor estrogen mempengaruhi ekspresi gen yang mengatur jumlah kanal $\mathrm{Ca}^{2+}(14)$. Selain itu, genistein juga merupakan inhibitor tyrosine kinase yang dapat mempengaruhi aktivitas berbagai kanal ion baik melalui proses phosphorilasi maupun ikatan langsung (8).

Penurunan frekuensi denyut jantung pada paparan sejak 2 hpf lebih dikarenakan hambatan perkembangan jantung. Paparan genistein pada $2 \mathrm{hpf}$ dapat mempengaruhi proses pembelahan dan proliferasi sel saat embryogenesis. Topoisomerase II dan PTKs terlibat dalam pengaturan siklus sel ini, sehingga genistein sebagai inhibitor topoisomerase II dan PTKs dapat memodulasi proses yang terjadi selama siklus sel (4). Pada paparan sejak $24 \mathrm{hpf}$, penurunan frekuensi denyut jantung dapat disebabkan defek morfologi jantung maupun gangguan fungsi jantung. Dari hasil studi terdahulu, diduga gangguan fungsi jantung ini akibat tidak adanya kontraksi ventrikel (ventricular standstill) akibat kegagalan aksi potensial untuk menjalar ke AV junction, atau aksi potensial sampai ke ventrikel tetapi terdapat blok pada kontraksi (11). Efek paparan genistein sejak $48 \mathrm{hpf}$ cenderung akibat gangguan fungsi jantung karena pada $48 \mathrm{hpf}$ jantung sudah berdenyut dan morfogenesis hampir sempurna (11). Menurut penelitian Antkiewicz et al, edema perikardium diduga tidak berefek secara langsung pada denyut jantung. Untuk mengetahui lebih jelas perlu penelitian lebih lanjut dengan memeriksa histologi jantung dan penggunaan bahan osmotik untuk menghambat terjadinya edema perikardium.

Dari penelitian ini dapat disimpulkan bahwa semakin awal pemaparan genistein pada embrio maka semakin besar terjadinya edema pericardium dan penurunan frekuensi denyut jantung zebrafish. Hal ini menunjukkan bahwa pemberian genistein pada tahap embriogenesis menyebabkan gangguan pembentukan jantung.

Model for In Vivo Drug Discovery and Develoment. Current Drug Metabolism. 2009; 10(2): 116-124.

6. Denvir MA, Tucker CS, and MulliasJJ. Systolic and Diastolic Ventricular Function in Zebrafish Embrios Influence of Norepinephrine, MS-222 and Temperature. Biomed Central. 2008; 8: 21.

7. Dixon RA and Ferreira D. Genistein. Phytochemistry. 2002; 60(3): 205-211.

8. Kim DJ, Seok SH, Baek MW, et al. Developmental Toxicity and Brain Aromatase Induction by High Genistein Concentrations in Zebrafish Embryos. Toxicology Mechanisms and Methods. 2009; 19(3): 251-256.

9. Westerfield M. The Zebrafish Book. A Guide for the Laboratory Use of Zebrafish (Danio Rerio). 4th edition. Eugene: University of Oregon Press; 2000. 
10. Kishida M, Tchoudakova A, Miller DS, and Callard G.Analysis of the Goldfish Carassius Auratus Aromatase P450arom Gene Promoters by Green Fluorescent Protein GFP Expression in Living Zebrafish Danio Rerio Embryos. Bulletin of the Mount Desert Island Biological Laboratory. 1999; 38: 37-38.

11. Antkiewicz DS, Burns CG, Corney SA, Peterson RE, and Herdeman W. Heart Malformation is an Early Response to TCDD in Embryonic Zebrafish. Toxicological Sciences. 2005; 84(2): 368-377.
12. Hoage $\mathrm{T}$,Ding $\mathrm{Y}$, and $\mathrm{Xu} \mathrm{X}$. Quantifying Cardiac Functions in Embryonic and Adult Zebrafish. Methods in Molecular Biology. 2012; 843: 11-20.

13. Kimmel CB, Ballard WW, Kimmel SR, Ullmann B, and Schilling TF. Stages of Embryonic Development of Zebrafish. Developmetal Dynamics. 1995; 203(3): 253310.

14. Babiker FA, De Windt LJ, van Eickels M, Grohe C, Meyer $\mathrm{R}$, and Doevendans PA. Estrogenic Hormone Action in the Heart: Regulatory Network and Function. Cardiovascular Research. 2002; 53(3): 709-719. 